\title{
The Petition on the Early English Stage
}

\author{
SCOTT OLDENBURG
}

In one of the many episodes in the anonymous play A Most Pleasant and Merie Nevv Comedie, Intitled, A Knacke to Knowe a Knave (1592), a miller, a smith, and a cobbler debate who should present their petition on behalf of the town of Gotham to King Edgar. ${ }^{1}$ Although seemingly superfluous to the main plot, the scene was noteworthy enough to be included as part of the extended title of the play: With Kemps Applauded Merrimentes of the Men of Goteham, in Receiuing the King into Goteham. The highlighting of this skit was in part due to the growing celebrity of William Kemp and the popularity of Andrew Boorde's jest book, Merie Tales of the Mad Men of Gotam (1565). ${ }^{2}$ The malapropisms and faulty logic of the townsmen provide comic relief in an otherwise serious play about corruption at Court and in the Commonwealth. The scene is rendered more farcical when it is discovered that the petition itself is aimed not at the pressing socioeconomic and political issues of the play but rather at securing the right to compel travelers (beginning presumably with the king and his entourage) to purchase locally brewed ale.

Prior to this farcical scene of petitioning is a more serious moment in which the character Honesty takes Piers Plowman to present his petition to the king (E3r). ${ }^{3}$ Piers complains that he and his family have been forced to "beg for maintenance" by an "unknown farmer" who is actively amassing land on the countryside (E3r). It is then revealed that the mysterious farmer goes by the name Walter Would-Have-More, an acquisitive farmer

Scott Oldenburg's first book, Alien Albion: Literature and Immigration in Early Modern England (2014), examines the ways in which several early modern texts counter xenophobic tendencies and imagine multicultural communities founded on shared religion or craft. He is working on a book about artisan poets in sixteenth-century England. 
who has bought his way into the king's favor (E3v). The clerk of the Assizes enters to confirm that Walter is guilty of a long list of crimes against the poor, including engrossing corn, unreasonably raising rents, and generally harassing the poor with suits. Walter, the figure of voracious self-interest, is further found guilty of having "conueyed corne out of the land to feede the Enemie" (E3v). Thus, in Knack, oppression of the poor is enmeshed with betrayal of national interest. The episode is one of several in which Honesty proves his titular skill to "know a Knaue" when he sees one, but it also complements Kemp's scene, offering a serious treatment of petitioning on behalf of the commons (A3r). In fact, it might be said that the jovial petitioning of the men of Gotham is made possible by Honesty's righting of the realm in the previous petitioning scene. But Knack is not unusual in its staging of petitioning. Whether in the anonymous Knack or Shakespeare's The Second Part of Henry the Sixth (1591), such scenes typically focus on a stage property that, outside of the theater, could be a fairly benign or politically vexed object. Even the humblest of supplications could carry with it a kind of audacity, a reminder that the social order was not exclusively top-down; its foundations could work from the bottom up with the expectation of reciprocal obligations. Thus the petition as stage property could evoke a wide range of political possibilities for a play and its audience.

Through the figure of Piers and his petition, notes Mike Rodman Jones, Knack alludes to a long tradition of religious and agrarian complaint. ${ }^{4}$ Entering into theological and socioeconomic debates of its time, William Langland's fourteenth-century allegorical poem, The Vision of Piers Plowman, circulated in manuscript form until 1550, when it was printed by Robert Crowley. Matthew Giancarlo examines the impact of parliamentary discourse and petitioning specifically on Piers Plowman and the immediate Piers Plowman tradition of fifteenth-century poems such as Mum and the Sothsegger and The Crowned King. ${ }^{5}$ Andrew McRae and Sukanta Chaudhuri further chart the tradition of appropriating the figure of Piers for the purpose of religious and social commentary well into the sixteenth century. ${ }^{6}$ For instance, Piers makes an appearance in the mid-Tudor anti-enclosure dialogue, Jack of the Northe, in which Piers laments that England is populated with so many men "Ever desyryng to take monye / As gredye of it as bees of honye." This connection is especially significant, as Michael Johnston argues, because Crowley's printing of Langland's poem was in response to the mid-Tudor rebellions in East Anglia and Norfolk prompted in part by protests of enclosures. ${ }^{8}$ In ad- 
dition, the figure of Piers speaks on behalf of the poor in Newes from the North (1579), a wide-ranging dialogue about social ills in England. ${ }^{9}$ As Steven Justice shows, the tradition dates back to Langland's own lifetime when, in 1381, John Ball and other leaders of the Peasants' Revolt alluded to the poem. ${ }^{10}$ Knack continues in this tradition, not for the purpose of sedition but rather to demonstrate the positive productivity of officially sanctioned channels of petitioning.

Indeed, upon receiving the petition, Edgar declares, "I haue heard my father say, / That piers plowman was one of the best members in a commonwealth" (E3r). In addition to acknowledging the importance of agrarian labor, Edgar's praise of Piers may signal one way in which petitions were understood. They provided useful information for the management of the realm. The supplication could further function as a kind of gift, ritualistically reasserting the addressee's prestige and authority. ${ }^{11}$ Nevertheless, a petition could also risk challenging authority. R. W. Hoyle singles out as the most radical those petitions representing a collective will, petitions on behalf of members of a particular craft or town. ${ }^{12}$ In displaying the commons' ability to organize around a cause, such petitions had a strong association with coordinated riot. Knack seems to invert such expectations, however, as the collective petition on behalf of Gotham turns out to be laughable, whereas the petition brought by the individual Piers offers a crucial intervention in Walter's primitive accumulation of capital. ${ }^{13}$ The former scene fits well with Maya Mathur's observation that in the early 1590s potentially radical figures of the commons were frequently rendered clownish on the stage. ${ }^{14}$ The latter scene emphasizes the progressive potential of petitions for the realm.

Petitioning scenes are ubiquitous in early English drama and usually function to depict and to critique how justice functions in the world of the play. For example, in a scene from the anonymous play Nobody and Somebody (1592), King Archigallo is presented with three petitions. ${ }^{15}$ In the first, Lord Morgan and Lord Malgo request the king to arbitrate their dispute over the possession of "the Southern Island." Archigallo shockingly rules that the isle shall become his own possession (lines 71-104, 80). ${ }^{16}$ Immediately following this ruling, two commoners-an unnamed Clown and Rafe-petition the king to rule on who has the right to be married to a nameless maid described by the king as "a pretty, neat, brown wench" (line 129). Rather than settle the case, however, the king decides to make the maid a lady, presumably with the aim of garnering sexual favors from her, while Rafe and the Clown 
are dismissed by Archigallo's advisor, Lord Sicophant. Archigallo then reads the third petition and declares,
What's here? Complaints against one Nobody
For overmuch relieving of the poor,
Helping distressed prisoners, entertaining
Extravagants and vagabonds. What fellow's this?

(lines 156-60)

Rather than read the petition as a complaint about mismanagement in Archigallo's realm (nobody is helping the poor), the petition is comically interpreted as a complaint about an actual character named Nobody (who actually turns out to exist in the play), and much of the play is devoted to a competition between the eponymous characters, Nobody and Somebody. ${ }^{17}$ As Anthony Archdeacon notes, this petitioning scene, which dramatizes the tyranny that had up to this point only been described in rumors, marks the play's crucial shift from history to farce. ${ }^{18}$

Petitioning scenes reflect a familiar practice in early modern England, an essential element of communication between subjects and their monarch. Ethan H. Shagan, for example, argues that petitions provided an important "feedback" mechanism in Tudor governance, and Hoyle suggests that the petition was so essential to Tudor politics that there was "a constant stream of members of the commons petitioning government for the exercise of its discretion." ${ }^{19}$ Peter Lake and Steve Pincus note the important role petitioning had in establishing a public sphere, while Annabel Patterson finds petitions in late sixteenth- and early seventeenth-century England so prevalent that she labels England a "petitioning society" as she charts the increased force attached to petitions leading to the Petition of Right in $1628 .^{20}$

Nobody and Somebody in particular demonstrates some of the diverse functions of the petition in early modern England. Petitions might request judgment on a dispute, register a complaint, or seek relief, special privileges, or favor. Sometimes referred to as supplications or, in certain cases, bills, petitions could be submitted by anyone in the realm: commoners, elites, women, men, individuals, or groups. They might be addressed to the king, Parliament, powerful lords, or other figures of authority. Nobody and Somebody features petitions on property disputes, domestic issues, and larger political failures from elites, commoners, andin the case of the petition against Nobody-a group or individual claiming to speak on behalf of the Commonwealth. 
Writing a petition involved considerable skill. Angel Day's epistolary manual, The English Secretorie (1586), provided several pages on petitions, but because successful petitions generally followed a formula and carefully constructed rhetoric of deference, petitioners, especially commoners, tended to employ a scribe or local lawyer to draft the document. ${ }^{21}$ Even when employing a clerk to help deliver the petition, there was a preference for petitions submitted in person, so between preparation of the document and travel, petitioning could constitute a considerable expense and effort for a commoner. ${ }^{22}$

The petition itself was almost always a single sheet of paper folded with the addressee's name on the outside and the carefully crafted complaint or request on the inside. Thus when a nameless petitioner in The Weakest Goeth to the Wall (1591-1600) is asked by the Duke of Bullen, "What's your suit?," the petitioner replies, "This paper will unfold, / If please you take perusal of the same."23 The petitioner's use of "unfold" is both metaphorical (a figure for revelation) and literal (a gesture toward the stage property-the folded paper-he presents to the duke). ${ }^{24}$

Frances Teague asserts that while a stage property can function in many ways, it often "serves as a figure for a character, a token of identity," or what Andrew Sofer more recently describes as "identity metonymies." 25 A crown, hat, or cap marked social status while a sword, spade, or other instrument might suggest occupation. The petition necessarily signals that the bearer is a petitioner, and this, along with the sometime-stated contents of the petition, is often all one knows about the character. In addition to The Weakest Goeth to the Wall, unnamed petitioners appear in Shakespeare's 2 Henry VI, part one of Thomas Heywood's Fair Maid of the West (1610), John Webster's Appius and Virginia (1625-27), William Heminge's The Fatal Contract: A French Tragedy (1633-34), Richard Brome's The Queen and Concubine (1635), George Chapman's The Tragedy of Chabot, Admiral of France (1622), and James Shirley's The Royal Master (1638) and The Sisters (1642), among others, while Thomas Preston's A Lamentable Tragedy Mixed Ful of Pleasant Mirth, Conteyning the Life of Cambises King of Percia (1569) renders the petitioner as an abstraction, an allegorical character named Commons Complaint. ${ }^{26}$ Similarly, plays such as George Whetstone's The Seconde Parte of the Historie of Promos and Cassandra (1577) feature "poore Citysens," or "a Poore man" as petitioners. ${ }^{27}$ This is not to say that protagonists never act as petitioners. Although it is not clear that she ever actually submits a piece of paper to 
Promos, the Argument to the first part of The Historie, of Promos and Cassandra (1577) describes Cassandra as submitting "an humble petition to the Lord Promos." ${ }^{8}$ More often than not, however, named petitioners, such as Master Butler in Sir John Oldcastle (1599) or Arthur Crosse in The Famous History of the Life and Death of Captain Thomas Stukeley (1596), appear to be only slightly more developed than their nameless counterparts. Perhaps playing with the stage convention, in John Day's early Jacobean satire The Ile of Guls (1606), the protagonists Amintas and Julio disguise themselves as a poor soldier and a poor scholar respectively to submit their petitions. ${ }^{29}$

Unlike most hand properties that identify the role being played, the petition does not typically remain in the possession of the petitioner. Upon submission to the addressee, the stage petition takes on a new meaning for the audience. While the petitioner was motivated by need and deployed a rhetoric of powerlessness and deference, the monarch or local lord was not (as Archigallo would have it) entirely free to be capricious or merely self-interested. Hearing petitions was a part of one's duties, and, as R. A. Houston emphasizes, one should not underestimate "the coercive force of moral obligation" and the need to maintain authority by at least appearing just. ${ }^{30}$ When Archigallo abuses his power in the petitioning scene of Nobody and Somebody, Lord Cornwell warns him that such acts will inspire "the common hatred of your subjects" (line 155). That is, when a petition is passed to the character in authority on the early English stage, the property might come to symbolize social or political obligation. The duke or king might act magnanimously or prudently but is not supposed to act arbitrarily or selfishly. After all, Archigallo's denial of various petitions sets in motion the discontent that leads to a full-scale rebellion in the play, supported in part by the lords whom he had wronged.

A similar sense of the petition symbolizing failed obligation occurs in Thomas Dekker's If This Be Not a Good Play, the Devil Is in It (1611). Toward the beginning of the play, the newly crowned King of Naples plans out his week according to a model of good government: on Mondays, he explains, he will act as judge and, on “Tuesdays, we'll sit to hear the poor man's cries, / Orphans and widows: our own princely eyes / Shall their petitions read." ${ }^{1}$ Although Ruffman, the devil, is on his way to corrupt the king, the scene already reveals problems at Court: Count Jovinelli consistently jokes about more trivial plans for the week, plans that in many ways come to fruition as Ruffman influences the Court. 
By act III, Octavio- the dutiful advisor to the king-enters with petitions declaring,

If now thou art a just King, keep thy word, With thy poor subjects

This is thy day to hear the poor man's cry:

And yonder's crying enough, at the Court gates;

Five hundred white heads, and scarce ten good hats,

Yet haberdashers too, of all trades some,

Crying out they are undone. ${ }^{32}$

Octavio blames the pomp of courtiers surrounding the king, but the pressure on the king at the delivery of these petitions is palpable. After listing the various wrongs described in the petitions, Octavio asks, "How wilt thou stop their throats?" to which the misguided king replies, "With halters." ${ }^{33}$ As with Nobody and Somebody, the petitioning scene underlines the failings of the monarch: just as the king replaces good counselors with bad, so reciprocal relations of the play's social order are replaced by brute force. Thus, the stage petition often enters into a dynamic exchange emblematic of the mutual obligations of petitioner and petitioned. When petitioning fails in these plays, the society depicted is typically on the brink of social upheaval.

Yet the use of the stage petition is not limited simply to passing it from petitioner to authority. Douglas Bruster notes that stage properties often appear in contemporary accounts of plays when they are subjected to a "breach of decorum," when something unexpected is done with them. ${ }^{34}$ While the king's suggestion to hang all petitioners in If This Be Not a Good Play fits this failure to respond appropriately, the material petition is also sometimes subjected to a lack of proper decorum. In The Spanish Tragedy (1587), a play known for its highly symbolic use of stage properties, Hieronimo grieves the loss of his son and resolves to be patient in his desire for revenge when he is visited by petitioners-three nameless Citizens and one Old Man. ${ }^{35}$ The First Citizen describes Hieronimo to his fellow petitioners:

So I will tell you this: for learning and for law,

There is not any advocate in Spain

That can prevail, or will take half the pain

That he will, in pursuit of equity. ${ }^{36}$ 
Hieronimo is evidently well known as an advocate for commoners. This new information about him is especially cutting since, in the first Quarto of the play, this scene directly follows one in which, at Lorenzo's encouragement, the king ignores Hieronimo's suit for justice in seeking his son's murderers. Despite Hieronimo's reputation, the ordinary channels of justice fail him. Still, Hieronimo imagines that the petitioners will provide a welcome distraction from his own woes.

As with several other petitioning scenes, this one emphasizes the range of issues addressed by petitions: leases, debts, and legal actions. The Old Man, at this point identified as Don Bazulto, submits to Hieronimo "[t]he humble supplication / Of Don Bazulto for his murdered son" (III.xiii.77-8). The petition's uncanny echo of Hieronimo's own predicament prompts Hieronimo to rebuke himself:

If love's effects so strives in lesser things, If love enforce such moods in meaner wits, If love express such power in poor estates, Hieronimo, whenas a raging sea

Tossed with the wind and tide o'erturneth thee, The upper billows' course of waves to keep, Whilst lesser waters labour in the deep, Then shamest thou not, Hieronimo, to neglect The sweet revenge of thy Horatio?

(III.xiii.98-106)

Implored from below, ignored from above, Hieronimo bemoans his political paralysis here. Building on the work of C. L. Barber, Kevin Dunn relates this sense of frustration to Hieronimo's unique class position: he is to both assert advice as a counselor and to appear disinterested-that is, he must express agency without subjectivity-resulting in his disdain for Bazulto's class as well as shame for his own failings to live up to Bazulto's ability to act upon injustice. ${ }^{37}$

The complicated grammar of Hieronimo's sentence, moreover-three conditional clauses ending with "poor estates," followed by a simile about waves subjected to wind and tide while undercurrents remain steadfast, before getting to the main clause, which turns out to be a question-reflects Hieronimo's own complex and labyrinthine thoughts. Hieronimo refers to Bazulto as "father" only to confuse Bazulto with the ghost of Hieronimo's son almost sixty lines later (III.xiii.73 and 130). Between these 
moments of misidentification, Hieronimo imagines that Horatio's murderers are present and declares, "Then will I rend and tear them thus and thus, / Shivering their limbs in pieces with my teeth" (III.xiii.121-2). At this moment, Hieronimo tears the petitions, apparently with his teeth. He does not seem really to intend to ruin the petitions; they are merely the inanimate casualties of his revenge reverie. Nevertheless, the man who would advocate on behalf of petitioners instead destroys the petitions. Hieronimo's fantasy of revenge bars the normal paths of redress from others even as it symbolizes his own abandonment of the state's system of justice.

The Spanish Tragedy's petitioners then reproach Hieronimo for tearing their papers. The First Citizen cries, "O sir, my declaration!," while the third declares, "Alas, my lease! It cost me / Ten pound, and you, my lord, have torn the same" (III.xiii. 123-5). The objections emphasize that for the petitioners these are not casual pieces of paper but important documents, even if they are common enough to a man of Hieronimo's status. Hieronimo denies that he has done harm, stating, "That cannot be, I gave it never a wound. / Show me one drop of blood fall from the same" (III.xiii.126-7). The imagery of Hieronimo's defense, confusing ink with blood, nonetheless betrays the vital importance of petitions and the pains commoners might go to in drafting and submitting them..$^{38}$ In Hieronimo's metaphor, to tear the petitions is to assault the foundation of reciprocal social relations in the world of the play, to wound the commons and draw blood from the body politic.

That the tearing of petitions was a striking scene for playgoers is perhaps most apparent in Shakespeare's borrowing of the idea for 2 Henry VI. ${ }^{39}$ Early in the play, a group of petitioners seek the Lord Protector, Duke Humphrey, who, as the second petitioner in the Quarto of the play explains, is a well-known advocate for poor petitioners. Like the praise of Hieronimo in The Spanish Tragedy, the second petitioner declares,

I pray God saue the good Duke Humphries life, For but for him a many were vndone, That cannot get no succor in the Court. ${ }^{40}$

Rather than Duke Humphrey, the petitioners encounter and are compelled to submit their petitions to the Duke of Suffolk and Queen Margaret. The petitions again are diverse: an individual complaining of personal wrongs, an apprentice complaining about his master, and a collective petition protesting enclosures. 
When the first petitioner complains of "John Goodman, my Lord Cardinal's man, for keeping my house and lands and wife and all from me," Suffolk seems to belittle the petitioner's misfortunes. ${ }^{41}$ Another intercepted petition comes from the only named petitioner, Peter Thump, complaining that his master claims that the Duke of York is the rightful heir to the throne, a petition Suffolk uses to his advantage to cause problems for his political rival. Still another petition is against Suffolk himself "for enclosing the commons of long Melford" (TLN 333-4). In the Quarto, this petition, representing the "whole township," prompts Suffolk to tear the petitions and declare,

So now show your petitions to Duke Humphrey.

Villaines get you gone and come not neare the Court, Dare these pesants write against me thus.

(TLN 336-8)

The Quarto's sequence thus culminates with the radically collective anti-enclosure petition. The fact that the petition is barred by the accused encloser himself and that it leads to his outrage and tearing of petitions emphasizes the vulnerability of the commons to the political whims of the elite and the topical importance of enclosures to the play. ${ }^{42}$ Suffolk's epithet, "Villaines," reinforces this point. Although the word denotes lowly, troublesome people, it also carries its feudal root: villeins were unfree peasants with little to no legal standing in relation to their lord. ${ }^{43}$ This episode also highlights Patterson's claim that there existed an intimate link between collective petitioning and "dangerous militancy." ${ }_{4}$ Rather than a convenient excuse for rebellion on behalf of York, Jack Cade's rebellion appears as the natural outcome of the ruling class's failure to respond appropriately to the petitions from the commons.

The folio effaces some of this. The praise of Humphrey as a champion for poor petitioners is reduced to a pun on the title Lord Protector: "Marry, the Lord protect him, for he's a good man! / Jesu bless him!" (I.iii.4-5). ${ }^{45}$ Suffolk's outrage is also downplayed. The anti-enclosure petition is presented second rather than last and elicits no more from Suffolk than "How now, sir knave!" as he moves on to the third petition against Peter Thump's allegedly Yorkist master (I.iii.21-2). More significantly, the folio specifies that Margaret rails against the commoners, expressing exasperation with the practice of petitioning and jealousy of the commons' admiration for Humphrey: 
And as for you, that love to be protected Under the wings of our Protector's grace, Begin your suits anew, and sue to him.

At this point Margaret, not Suffolk, tears the petitions and announces her own class revulsion: "Away, base cullions!" (I.iii.41). Jean E. Howard and Phyllis Rackin have shown how 2 Henry VI pins much of the disorder in the realm on female ambition. Margaret's destruction of the petitions and disdain for the petitioners in the folio only adds more evidence to their thesis. ${ }^{46}$

Moreover, insofar as 2 Henry VI is about Englishness or English national identity, the fact that the petitions are torn not just by a woman, but specifically by a French woman is particularly significant. ${ }^{47}$ Although petitions were no less important in early modern France, Margaret acts as though the episode has underscored a major cultural and political difference for her. ${ }^{48}$ She laments,

My Lord of Suffolk, say, is this the guise, Is this the fashions in the court of England?

Is this the government of Britain's isle, And this the royalty of Albion's king?

Margaret quickly goes on to complain that Henry is subservient to "the surly Gloucester's governance" (I.iii.48), but it is clear in the opening of the speech that the "this" of her tirade is the petitioning scene itself, triggering what Nicholas Grene describes as Margaret's "arbitrary contempt for law and due process." 49 Like Coriolanus, Margaret is repulsed by the idea that there is even a venue for commoners to voice their concerns. ${ }^{50}$ She then waxes nostalgic about tournaments in Tours, and the contrast is complete: grubby petitioning commoners in England and shining knights jousting in France. Petitioning was practiced throughout early modern Europe, but Margaret's rejection of the petitioners in 2 Henry VI presents petitioning as an especially English, almost patriotic, activity, one that connects commoners to Court in a national project distinct from that of France.

Whether the folio or Quarto is given preeminence, both employ the stage direction about tearing the petition. ${ }^{51}$ Even if the Quarto is a memorial reconstruction, the tearing of the petitions proves 
to be a particularly memorable event in the play. Rackin argues that the scene demonizes Suffolk and especially the queen while ideologically exculpating "the older aristocracy, represented by the good Duke of Gloucester." 52 To some degree, however, the scene also vindicates the commons. Some critics have taken issue with the anti-literacy element of Cade's rebellion later in the play, in which the rebels try the clerk of Chartham for being able to write his name and Cade commands them to "burn all the records of the realm" (IV.ii.78-101 and IV.vii.12). ${ }^{53}$ But committing one's name to a legal document is precisely what commoners did in the petitioning process. The petitioning scene emphasizes the commoners' reliance on writing while the same scene depicts the elites' rejection of the written word when it fails to serve the interests of those in power. As Craig A. Bernthal has argued, the scene shows the decay of the judicial system in England and therefore makes sense of Cade's rebellion later in the play. ${ }^{54}$ The rebels' objection to writing, then, mirrors-even parodies-the ruling class's previous destruction of the petitions. The disruption of legal recourse for commoners results in a similar, albeit greatly amplified, disruption of ruling-class legal documentation.

In case the point is missed, the folio includes another petition, one apparently submitted by the rebels at the height of the rebellion. ${ }^{55}$ Act IV, scene iv begins with the stage direction, "Enter the KING with a supplication, and the QUEEN with Suffolk's head." Suffolk, the queen, a petition-the scene seems intent on recalling the earlier petitioning scene, but, instead of torn petitions, there is the severed head of the enclosing lord, and the grieving queen replaces the dismayed petitioners. ${ }^{56}$ This tableau thus connects the rebels' petition to the king to the obstruction of the commoners in the earlier petitioning scene.

Shakespeare was certainly drawing on Thomas Kyd for the tearing of petitions scene, but he and Kyd, similar to the author(s) of Knack, were also probably alluding to Langland's The Vision of Piers Plowman. ${ }^{57}$ In Crowley's sixteenth-century edition of the poem (based on the B-text), Truth presents Piers with a pardon written in Latin; Piers then finds a priest to examine the pardon. Unfolding the pardon (not unlike the unfolding of a stage petition), the priest accurately glosses the paper for Piers as simply "do wel and haue wel, and god shal haue Pi soule." ${ }^{8}$ It does not pardon; it merely paraphrases Matthew 25. At this point, Piers, "for pure tene," or anger, "pulled it [asonder]" (VII.1 19). ${ }^{59}$ Although interpretations of this episode vary widely, several critics argue that Piers's anger is directed not at the pardon but at the priest 
who attempts to assert interpretive authority over him. ${ }^{60}$ By the same token, Hieronimo imagines his gesture aimed at the murderers of Horatio rather than at the petition or petitioners. In that sense, tearing documents seems to be a protest of authority. Suffolk and Margaret of 2 Henry VI may be authority figures, but their destruction of petitions is very much an objection to the legitimate position of Duke Humphrey as Lord Protector and, more importantly, the authority of the petitioning process itself.

Other critics of Piers Plowman read the tearing of the pardon as a rejection of the old law of retribution in favor of the new law of mercy. ${ }^{61}$ The Spanish Tragedy and 2 Henry VI secularize and invert this movement. Individuals take the law into their own hands, rebelling against the failures of justice in their respective societies. Hieronimo and his accomplice Isabella take revenge on Horatio's murderers, the princes of Spain and Portugal, while the commoners in 2 Henry VI forego legal remedies and follow Cade in rebellion. Indeed, viewing 2 Henry VI through the lens of The Spanish Tragedy brings into focus the idea that rebellion might be read as a kind of collective revenge, or that revenge might be seen as a form of individual rebellion. ${ }^{62}$

But Piers Plowman also has its connection to popular rebellion. The letters of the leaders of the 1381 Peasants' Revolt allude to the character Piers as a "brother," and John Ball evidently drew upon the poem in his sermon at Blackheath. ${ }^{63}$ Several critics argue that Langland revised his poem in what is now known as the C-text version to distance himself from the revolt. For fear of being associated with the rebels' destruction of judicial records (which Shakespeare projected onto Cade's rebellion), for example, Langland appears to have removed the tearing of the pardon from the poem altogether. ${ }^{64}$

The Spanish Tragedy too underwent revision for the 1602 Quarto. ${ }^{65}$ Among the changes, there seems to be a similar distancing of the play from popular politics. Although the petitioning scene with Bazulto appears in the 1602 Quarto, most scholars agree that, in performance, the intent was to replace that scene with one in which Hieronimo discusses art and loss with a painter named Bazardo. ${ }^{66}$ In this replacement scene Hieronimo identifies not with a group of aggrieved commoners but with a grieving artist; thus, popular politics would give way to introspection and a reflection on aesthetics. Similarly, although the folio of 2 Henry VI retains the petitioning scene, the later version of the play clearly underwent substantial changes. In the folio, the anti-enclosure petition is tucked away as the second petition so that it does not 
appear to be the one triggering Suffolk and Margaret's outrage. And, as has already been noted, the play appears to have been revised so that the tearing of the petitions is carried out not by the English-born Suffolk but rather by a meddlesome foreigner, Margaret.

The revision of these plays points to a pattern of suppressing or otherwise tempering the radical potential of petitioning scenes. ${ }^{67}$ In that sense, the revisions attest to the enduring political valence and populist appeal of the petition on the early English stage. At the same time, it should be noted that most of the plays discussed here are from the early 1590s. Despite some notable exceptions, it is clear that the petitioning scene, at least in its populist form, was in decline by the late 1590s. ${ }^{68}$ This coincides with other shifts in early modern playing: the establishment of indoor theaters, the reconstitution of the boys' companies, and the use of smaller casts. Indeed, by 1596, the Chamberlain's Men were the target of a petition objecting to James Burbage's attempt to establish an indoor theater for the company in the fashionable neighborhood of Blackfriars. The theater had to be leased to the Chapel Children until 1608, when the adult company was able to take over the lease. ${ }^{69}$

Although the status of players had always been a vexed one, several players sought to identify more closely with the elite audience members attending the indoor theaters and Court performances. Edward Alleyn of the Admiral's Men, for example, apparently sought knighthood while using his wealth to found the school now known as Dulwich College. ${ }^{70}$ Members of the Chamberlain's Men-Shakespeare, Robert Armin, John Heminges, and Augustine Phillips-acquired coats of arms for their families. ${ }^{71}$ When King James I adopted the Chamberlain's Men as his own, they also became Grooms of the Chamber, not a paying position but one that granted them the status of royal courtiers and that allowed them to wear the royal livery. ${ }^{72}$

Several plays encourage such identification as they lambaste the tastes of commoners in the amphitheaters, where one might still see the occasional petitioning scene. In praise of the new indoor theater, Ned Planet of John Marston's Jack Drum's Entertainment (1600) declares, "A man shall not be choakte / With the stench of Garlicke, nor be pasted / To the barmy Iacket of a Beer-brewer." ${ }^{73}$ Forty years later, in Brome's The Antipodes: A Comedie (1636), Lord Letoy recalls the disappearance from the theater of bits such as the "Merrimentes of the Men of Goteham": 
Yes in the dayes of Tarlton and Kempe,

Before the stage was purg'd from barbarisme,

And brought to the perfection it now shines with. ${ }^{74}$

Like Margaret's contrast between English petitioners and French knights in 2 Henry VI, The Antipodes's comparison of base Tudor amphitheater and refined Stuart indoor theater ought not be taken as unquestionable documentary evidence of the actual circumstances in the playhouses. Such statements nonetheless give a sense of how the indoor theaters wanted to promote themselves. They advertised themselves as civil, private, and elite rather than rowdy, public, and common, and the scenes of their plays would seek to highlight that division.

Although Dekker continued in a populist vein in If This Be Not a Good Play at the Red Bull, fewer plays of the seventeenth century feature petitioning scenes. Those Stuart and Caroline plays that do feature petitions tended to downplay the popular politics with which the scene had been associated. For example, the petitioners in Chapman's The Tragedy of Chabot are silent observers of the title character's trial, and the petitioners in Shirley's The Sisters turn out to be con artists rather than aggrieved citizens.

One might well read Marston's What You Will (1601) as a late Elizabethan farewell to the petitioning scene of the 1580s and 1590s. Written for the Children of Paul's - a company that performed only for Court and for the private, indoor theaters-the play begins with a debate about the aesthetic judgment of the audience, a debate settled by a prologue spoken by "the Author," presumably Marston himself. ${ }^{75}$ The prologue spurns the idea of catering to popular tastes as laboring for "Sweet breath from tainted stomacks" and instead appeals to the cultivated tastes of "the faire proportion'd loues of witte," the elite audience of the boys' company. ${ }^{76}$ The play even includes a scene with a schoolmaster to remind the audience of the privileged background of the company. About a third of the way through the episodic comedy, the mad duke enters with courtiers and ladies. Exploiting the acoustics of the indoor theater, the scene features musical accompaniment. ${ }^{77}$ No words are spoken as the duke is presented with a petition. Rather than an examination of justice or a serious moment of reflection on the relation between Court and commoner in the play, the stage directions indicate that the duke silently thrusts the petition into the flame of one of the indoor theater's candles and "lightes his tobacco pipe with it." ${ }^{8}$ The duke then "goes out dauncing" in a trail of tobacco smoke, leaving the wealthy audi- 
ence of the indoor theater to prepare for the next scene as the last scrap of the stage petition smolders to ash. ${ }^{79}$

\section{NOTES}

${ }^{1}$ [William Kemp], A Most Pleasant and Merie Nevv Comedie, Intitled, A Knacke to Knowe a Knave (London: Richard Jones, 1594), E4r; EEBO STC (2d edn.) 15027. All subsequent references to A Knacke to Knowe a Knave, hereafter Knack, are from this edition and will appear parenthetically in the text by signature. Unless otherwise noted, dating of the plays discussed in this essay are from Martin Wiggins, British Drama, 1533-1642: A Catalogue, with Catherine Richardson, 10 vols. (Oxford: Oxford Univ. Press, 2012).

${ }^{2}$ Andrew Boorde, Merie Tales of the Mad Men of Gotam (London: Thomas Colwell, 1565); EEBO STC (2d edn.) 1020.5. Despite the allusion to the "Men of Goteham," the petitioning episode does not appear in Boorde's book.

${ }^{3}$ On the figure of Honesty in the play, see Paul A. Jorgenson, "The Metamorphosis of Honesty in the Renaissance," ELR 3, 3 (Autumn 1973): 369-79. On the serious allegory of the play, see David J. Houser, "Purging the Commonwealth: Marston's Disguised Dukes and A Knack to Know a Knave," PMLA 89, 5 (October 1974): 993-1006; and Alan C. Dessen, "The 'Estates' Morality Play," SP 62, 2 (April 1965): 121-36.

${ }^{4}$ See Mike Rodman Jones, Radical Pastoral, 1381-1594: Appropriation and the Writing of Religious Controversy (Farnham UK: Ashgate, 2011), pp. $161-9$.

${ }^{5}$ See Matthew Giancarlo, Parliament and Literature in Late Medieval England (Cambridge: Cambridge Univ. Press, 2007), pp. 179-254.

${ }^{6}$ See Andrew McRae, God Speed the Plough: The Representation of Agrarian England, 1500-1660 (Cambridge: Cambridge Univ. Press, 1996), pp. 26-30; and Sukanta Chaudhuri, "Ploughman and Shepherd: Langland's Legacy to Tudor Pastoral," JDECU 22, 1-2 (1986-87): 50-71. See also Anne Hudson, "Epilogue: The Legacy of Piers Plowman," in A Companion to "Piers Plowman," ed. John A. Alford (Berkeley: Univ. of California Press, 1988), pp. 251-66; and Lawrence Warner, "Plowman Traditions in Late Medieval and Early Modern Writing," in The Cambridge Companion to "Piers Plowman," ed. Andrew Cole and Andrew Galloway (Cambridge: Cambridge Univ. Press, 2014), pp. 198-213. For a useful anthology of such texts, see The Piers Plowman Tradition, ed. Helen Barr (London: Everyman, 1993).

${ }^{7}$ Jack of the Northe, in Annals of Cambridge, ed. Charles Henry Cooper, 5 vols. (Cambridge: Warwick, 1843), 2:40-2, 41.

${ }^{8}$ Michael Johnston, "From Edward III to Edward VI: The Vision of Piers Plowman and Early Modern England," Reformation 11 (2006): 47-78. On these rebellions, see Andy Wood, The 1549 Rebellions and the Making of Early Modern England (Cambridge: Cambridge Univ. Press, 2007).

${ }^{9}$ F[rancis] T[hynne], Newes from the North (London: John Allde, 1579); EEBO STC (2d edn.) 24062.

${ }^{10}$ See Steven Justice, Writing and Rebellion: England in 1381 (Berkeley: Univ. of California Press, 1994), pp. 102-39 and 230-51. See also J. R. Maddicott, "Poems of Social Protest in Early Fourteenth-Century England," 
in England in the Fourteenth Century: Proceedings of the 1985 Harlaxton Symposium, ed. W. M. Ormrod (Woodbridge UK: Boydell Press, 1986), pp. 130-44, esp. 138-9.

${ }^{11}$ On the petition as gift, see R. A. Houston, Peasant Petitions: Social Relations and Economic Life on Landed Estates, 1600-1850 (Basingstoke UK: Palgrave Macmillan, 2014), pp. 104-7; and James Daybell, Women LetterWriters in Tudor England (Oxford: Oxford Univ. Press, 2006), pp. 145-50.

${ }^{12}$ R. W. Hoyle, "Petitioning as Popular Politics in Early Sixteenth-Century England," Historical Research 75, 190 (November 2002): 365-89, 366-7.

${ }^{13}$ For a discussion of primitive accumulation in this period, see Karl Marx, Capital: A Critique of Political Economy, trans. Ben Fowkes (New York: Vintage Books, 1977), pp. 873-944. See also Ellen Meiksins Wood, The Origins of Capitalism: A Longer View (London: Verso, 2002), esp. pp. 95-146; and Richard Halpern, The Poetics of Primitive Accumulation: English Renaissance Culture and the Genealogy of Capital (Ithaca: Cornell Univ. Press, 1991).

${ }^{14}$ See Maya Mathur, "An Attack of the Clowns: Comedy, Vagrancy, and the Elizabethan History Play," JEMCS 7, 1 (Spring/Summer 2007): 33-54.

15 "Nobody and Somebody": An Introduction and Critical Edition, ed. and introduction David L. Hay (New York: Garland, 1980), lines 73-165. All subsequent references to Nobody and Somebody are from this edition and will appear parenthetically in the text by line number. Nobody and Somebody was entered into the Stationers' Register in 1606, and Wiggins suggests that the play was performed between 1603 and 1606 (British Drama, 5:190). More recently, scholars have suggested that the play or some version of it was performed in the early 1590s. See, for instance, Hay's introduction to Nobody and Somebody, pp. 1-68, esp. 63-6; Roslyn L. Knutson, "The Start of Something Big," in Locating the Queen's Men, 1583-1603: Material Practices and Conditions of Playing, ed. Helen Ostovich, Holger Schott Syme, and Andrew Griffin (New York: Routledge, 2009), pp. 99-108, 106-7; and John E. Curran Jr., "Geoffrey Monmouth in Renaissance Drama: Imagining NonHistory," MP 97, 1 (August 1999): 1-20, 2n5.

${ }^{16}$ The island in question is not known, but it is likely the Isle of Wight.

${ }^{17}$ On the legal discourse surrounding the character Nobody, see Luke Wilson, Theaters of Intention: Drama and the Law in Early Modern England (Stanford: Stanford Univ. Press, 2000), pp. 238-49. On the performance history of the play, see Anston Bosman, "Renaissance Intertheater and the Staging of Nobody," ELH 71, 3 (Fall 2004): 559-85.

${ }^{18}$ See Anthony Archdeacon, "The Publication of No-body and Some-body: Humanism, History, and Economics in the Early Jacobean Public Theatre," EMLS 16, 1 (2012): 2, http://extra.shu.ac.uk/emls/16-1/archnobo.htm, par. 19.

${ }^{19}$ Ethan H. Shagan, "Protector Somerset and the 1549 Rebellions: New Sources and New Perspectives," English Historical Review 114, 455 (February 1999): 34-63, 41; and Hoyle, p. 389. See also Giancarlo, pp. 140-35.

${ }^{20}$ Peter Lake and Steve Pincus, "Rethinking the Public Sphere in Early Modern England," Journal of British Studies 45, 2 (April 2006): 270-92; and Annabel Patterson, Reading between the Lines (Madison: Univ. of Wisconsin Press, 1993), pp. 57-79, 57.

${ }^{21}$ Angel Day, The English Secretorie (London: Robert Walde-Grave, 1586), pp. 169-84; EEBO STC (2d edn.) 6401. 
${ }^{22}$ See Gwilym Dodd, Justice and Grace: Private Petitioning and the English Parliament in the Late Middle Ages (Oxford: Oxford Univ. Press, 2007), pp. 302-16; and Houston, pp. 80-6. At a cost of around two to five pence, paper itself was a fairly expensive commodity for a laborer (See Daybell, The Material Letter in Early Modern England: Manuscript Letters and the Culture and Practices of Letter-Writing, 1512-1635 [New York: Palgrave Macmillan, 2012], pp. 34-6).

${ }^{23}$ Jill L. Levenson, ed., A Critical Edition of the Anonymous Elizabethan Play "The Weakest Goeth to the Wall" (New York: Garland, 1980), I.126-7.

${ }^{24}$ A similarly metaphorical and literal use of "unfold" occurs in King Henry $V$ when Montjoy enters to report his "master's mind" (Shakespeare, King Henry V, ed. T. W. Craik [London: Routledge, 1995], III.vi. 115). Henry V commands, "Unfold it," and Montjoy seems then to read the letter (III.vii. 116).

${ }^{25}$ Frances Teague, Shakespeare's Speaking Properties (Lewisburg PA: Bucknell Univ. Press, 1991), p. 122; and Andrew Sofer, The Stage Life of Props (Ann Arbor: Univ. of Michigan Press, 2003), p. 21. For a useful discussion of the relationship between objects and identity in early modern drama, see Douglas Bruster, Drama and the Market in the Age of Shakespeare (Cambridge: Cambridge Univ. Press, 1992), pp. 63-96; and David M. Bevington, "The Language of Costume and Hand Properties," in Action Is Eloquence: Shakespeare's Language of Gesture (Cambridge MA: Harvard Univ. Press, 1984), pp. 35-66.

${ }^{26}$ The dates for these various plays can be difficult to ascertain. George Chapman's play in particular poses considerable problems pinning down a composition date-as early as 1611 , as late as 1635 . For the date given for Thomas Heywood's Fair Maid of the West, see Wiggins, 6:49. Unfortunately, the final volume of Wiggins's British Drama, containing the dates of plays from 1617 and onward, is not available at the writing of this article. For the dates for these later plays, see Chapman, The Plays of George Chapman: The Tragedies with Sir Gyles Goosecappe, A Critical Edition, ed. Allan Holaday (Suffolk UK: D. S. Brewer, 1987), pp. 617-8; William Heminge, The Plays and Poems of William Heminge, ed. Carol A. Morley (Madison NJ: Fairleigh Dickinson Univ. Press, 2006), pp. 263-7; and Sandra A. Burner, James Shirley: A Study of Literary Coteries and Patronage in Seventeenth-Century England (Lanham MD: Univ. Press of America, 1988), pp. 115 and 142. See also Thomas Preston, A Lamentable Tragedy Mixed Ful of Pleasant Mirth, Conteyning the Life of Cambises King of Percia (London: Iohn Allde, [1570]), Cv; EEBO STC (2d edn.) 20287. On petitioning in The Life of Cambises, see Mathur, "For All Kinde of Estates I Meane for to Trudge': Making Room for the Commoners in Cambises," ETREED 17, 2 (2014): 35-55.

${ }^{27}$ George Whetstone, The Seconde Parte of the Historie of Promos and Cassandra, in The Comedies, 1597-1603, vol. 2 of Narrative and Dramatic Sources of Shakespeare, ed. Geoffery Bullough, 8 vols. (London: Routledge and Kegan Paul, 1958), pp. 480-513, 491 and 500. For the date given for Whetstone, see Wiggins, 2:166.

${ }^{28}$ Whetstone, The Historie, of Promos and Cassandra, in The Comedies, pp. 444-80, 445.

${ }^{29} \mathrm{John}$ Day, The Ile of Guls ([London]: Printed for Iohn Trundle, 1606), Br; EEBO STC (2d edn.) 6412. 
${ }^{30}$ Houston, p. 272. See also Dodd, pp. 232-9.

${ }^{31}$ Thomas Dekker, If This Be Not a Good Play, the Devil Is in It, in The Dramatic Works of Thomas Dekker, ed. Fredson Bowers, 4 vols. (Cambridge: Cambridge Univ. Press, 1958), 3:113-223, I.ii.105-9. I have taken the liberty of modernizing the spelling for this play.

${ }^{32}$ Dekker, III.iii.64-70.

${ }^{33}$ Dekker, III.ii.90.

${ }^{34}$ Bruster, "The Dramatic Life of Objects in the Early Modern Theatre," in Staged Properties in Early Modern English Drama, ed. Jonathan Gil Harris and Natasha Korda (Cambridge: Cambridge Univ. Press, 2002), pp. 67-98, 74.

${ }^{35}$ For a discussion on the approximate date of composition and performance of The Spanish Tragedy, see Philip Edwards, introduction to The Spanish Tragedy, by Thomas Kyd, ed. Edwards (Cambridge MA: Harvard Univ. Press, 1959), pp. xvii-lxviii, xxi-xxvii. For a more recent appraisal, see Lukas Erne, Beyond "The Spanish Tragedy": A Study of the Works of Thomas Kyd (Manchester: Manchester Univ. Press, 2001), p. 56. On the use of stage properties in The Spanish Tragedy, see Sofer, Stage Life of Props, pp. 75-88; Andrew Hadfield, "A Handkerchief Dipped in Blood in The Spanish Tragedy: An Anti-Catholic Reference?,” N\&Q 47, 1 (June 1991): 197; and Janette Dillon, The Cambridge Introduction to Early English Theatre (Cambridge: Cambridge Univ. Press, 2006), pp. 101-2.

${ }^{36} \mathrm{Kyd}$, The Spanish Tragedy, ed. Clara Calvo and Jesús Tronch, Arden Early Modern Drama (London: Arden, 2013), III.xiii.51-4. All subsequent references to The Spanish Tragedy are from this edition, unless otherwise noted, and will appear parenthetically in the text by act, scene, and line number.

${ }^{37}$ Kevin Dunn, “'Action, Passion, Motion': The Gestural Politics of Counsel in The Spanish Tragedy," in "Performing Affect," ed. Jeffrey Masten and Wendy Wall, special issue, RenD, n.s., 31 (2002): 27-60.

${ }^{38}$ On the trope of blood and ink throughout the play, see David Cutts, "Writing and Revenge: The Struggle for Authority in Thomas Kyd's The Spanish Tragedy," ERC 22 (1996): 147-60.

${ }^{39}$ M. Rick Smith has made a similar connection in his article "Henry VI, Part 2: Commodifying and Recommodifying the Past in Late-Medieval and Early-Modern England," in Henry VI: Critical Essays, ed. Thomas A. Pendleton (New York: Routledge, 2001), pp. 177-204, esp. pp. 191-2.

${ }^{40}$ Shakespeare, "Appendix 1: The First Quarto (1594)," in King Henry VI Part 2, ed. Ronald Knowles, Arden Shakespeare (Surrey UK: Thomas Nelson and Sons, 1999), pp. 376-407, total line number 291-3. All subsequent references to the first Quarto of King Henry VI Part 2, hereafter 2 Henry VI, are taken from this photographic facsimile in the Arden edition "Appendix 1" and will appear parenthetically in the text by total line number, hereafter TLN.

${ }^{41}$ Shakespeare, 2 Henry VI, I.iii.16-8. All subsequent references to 2 Henry VI are from the Arden edition and will appear parenthetically in the text and notes by act, scene, and line number.

${ }^{42}$ On 2 Henry VI and the issue of enclosures, see Thomas Cartelli, "Jack Cade in the Garden: Class Consciousness and Class Conflict in 2 Henry VI," in Enclosure Acts: Sexuality, Property, and Culture in Early Modern England, ed. Richard Burt and John Michael Archer (Ithaca: Cornell Univ. Press, 1999), pp. 48-67; James R. Siemon, "Landlord Not King: Agrarian Change and In- 
terarticulation," in Enclosure Acts, pp. 17-33, esp. 25-6; William C. Carroll, Fat King, Lean Beggar: Representations of Poverty in the Age of Shakespeare (Ithaca: Cornell Univ. Press, 1996), pp. 127-57; and James Holstun, "Damned Commotion: Riot and Rebellion in Shakespeare's Histories," in A Companion to Shakespeare's Works, ed. Richard Dutton and Jean E. Howard, 4 vols. (Malden MA: Blackwell, 2003), 2:194-219.

${ }^{43}$ On the status of villeins in medieval England, see John Hatcher, "English Serfdom and Villeinage: Towards a Reassessment," in Landlords, Peasants, and Politics in Medieval England, ed. T. H. Aston (Cambridge: Cambridge Univ. Press, 1987), pp. 247-84; and Alan Harding, Medieval Laws and the Foundations of the State (Oxford: Oxford Univ. Press, 2001), pp. 222-6.

${ }^{44}$ Patterson, p. 78.

${ }^{45}$ Lost too is some of the specificity of the anti-enclosure petition wherein "long Melford" is reduced to simply "Melford" (I.iii.21).

${ }^{46}$ See Howard and Phyllis Rackin, Engendering a Nation: A Feminist Account of Shakespeare's English Histories (London: Routledge, 1997), pp. 65-82, esp. 72-5.

${ }^{47}$ On national identity in 2 Henry VI, see Dillon, Language and Stage in Medieval and Renaissance England (Cambridge: Cambridge Univ. Press, 1998), pp. 202-19; Abraham Oz, "Nation and Place in Shakespeare: The Case of Jerusalem as a National Desire in Early Modern English Drama," in PostColonial Shakespeares, ed. Ania Loomba and Martin Orkin (London: Routledge, 1998), pp. 98-1 16; David Steinsaltz, "The Politics of French Language in Shakespeare's History Plays," SEL 42, 2 (Spring 2002): 317-34; and Peter Womack, "Imagining Communities: Theatres and the English Nation in the Sixteenth Century," in Culture and History, 1350-1600: Essays on English Communities, Identities, and Writing, ed. David Aers (New York: Harvester Wheatsheaf, 1992), pp. 91-146, esp. 131-8.

${ }^{48}$ Indeed, petitioning was an integral part of political life throughout Europe. See, for example, Griet Vermeesch, "Professional Lobbying in Eighteenth-Century Brussels: The Role of Agents in Petitioning the Central Government Institutions in the Habsburg Netherlands," Journal of Early Modern History 16, 2 (2012): 95-1 19; Andreas Würgler, "Voices from Among the 'Silent Masses': Humble Petitions and Social Conflicts in Early Modern Europe," in "Petitions in Social History," ed. Lex Heerma van Voss, special issue, International Review of Social History 46, 9 (December 2001): 11-34; and Christopher R. Friedrichs, Urban Politics in Early Modern Europe (London: Routledge, 2002), pp. 38-45.

${ }^{49}$ Nicholas Grene, Shakespeare's Serial History Plays (Cambridge: Cambridge Univ. Press, 2002), p. 76.

${ }^{50}$ On Shakespeare's Coriolanus (1605-08), see Holstun, "Tragic Superfluity in Coriolanus," ELH 50, 3 (Autumn 1983): 485-507; and Arthur Riss, "The Belly Politic: Coriolanus and the Revolt of Language," ELH 59, 1 (Spring 1992): 53-75.

${ }^{51}$ On the differences between the Quarto and the folio, see Barbara Kreps, "Bad Memories of Margaret? Memorial Reconstruction versus Revision in The First Part of the Contention and 2 Henry VI," SQ 51, 2 (Summer 2000): 154-80; Roger Warren, "The Quarto and Folio Texts of 2 Henry VI: A Reconsideration," RESLJ, n.s., 51, 20 (May 2000): 193-207; Lawrence Manley, "From Strange’s 
Men to Pembroke's Men: 2 Henry VI and The First Part of the Contention," SQ 54, 3 (Autumn 2003): 253-87; Steve Urkowitz, “'Brother, Can You Spare a Paradigm?': Textual Generosity and the Printing of Shakespeare's MultipleText Plays by Contemporary Editors," in "Textual Shakespeare," ed. Graham Holderness and Andrew Murphy, CrSurv 7, 3 (December 1995): 292-306; and Leah S. Marcus, Unediting the Renaissance: Shakespeare, Marlowe, Milton (London: Routledge, 1996), pp. 31-2.

${ }^{52}$ Rackin, Stages of History: Shakespeare's English Chronicles (Ithaca: Cornell Univ. Press, 1990), p. 219.

${ }^{53}$ On 2 Henry VI and the issue of literacy, see Roger Chartier, "Jack Cade, the Skins of a Dead Lamb, and the Hatred of Writing," ShakS 34 (2006): 77-89; Frederick Kiefer, Writing on the Renaissance Stage: Written Words, Printed Pages, Metaphoric Books (Newark: Univ. of Delaware Press, 1996), pp. 78-80; Knowles, "The Farce of History: Miracle, Combat, and Rebellion in 2 Henry VI," in "Politics, Patronage, and Literature in England 1558-1658," ed. Andrew Gurr, special issue, YES 21 (1991): 168-86, 180-1; and Geraldo U. de Sousa, "The Peasants' Revolt and the Writing of History in 2 Henry VI," in Reading and Writing in Shakespeare, ed. David M. Bergeron (Newark: Univ. of Delaware Press, 1996), pp. 178-93.

${ }^{54}$ See Craig A. Bernthal, “Jack Cade’s Legal Carnival," SEL 42, 2 (Spring 2002): 259-72, 261-2.

${ }^{55}$ In the Quarto, this additional petition is described as a letter that appears to report offstage events.

${ }^{56}$ On body parts, particularly severed heads, as stage properties, see Margaret E. Owens, Stages of Dismemberment: The Fragmented Body in Late Medieval and Early Modern Drama (Newark: Univ. of Delaware Press, 2005); Sofer, “Take Up the Bodies': Shakespeare's Body Parts, Babies, and Corpses," in The Prop's the Thing: Stage Properties Reconsidered, ed. J. Curry, Theatre Symposium 18 (Tuscaloosa: Univ. of Alabama Press, 2011), pp. 135-48; and Lucy Munro, “They Eat Each Other's Arms': Stage Blood and Body Parts," in Shakespeare's Theatres and the Effects of Performance, ed. Farah KarimCooper and Tiffany Stern, Arden Shakespeare Library (London: Bloomsbury, 2013), pp. 73-93.

${ }^{57}$ On William Langland's influence on Shakespeare, see Eugenie Freed, “'Inn That Folie I Raigned ...': Reason, Justice, and the King in Piers Plowman and King Lear," Southern African Journal of Medieval and Renaissance Studies 13 (2003): 15-41; and Peter R. Moore, "Hamlet and Piers Plowman: A Matter of Conscience," CahiersE 65, 1 (May 2004): 11-24.

${ }^{58}$ Langland, Will's Visions of Piers Plowman, Do-Well, Do-Better, and DoBest, in Piers Plowman: The B Version, vol. 2 of Piers Plowman: The Three Versions, ed. George Kane and E. Talbot Donaldson, 3 vols. (Berkeley: Univ. of California Press, 1988), pp. 227-681, passus VII, lines 116. All subsequent references to Piers Plowman are from this edition and will appear parenthetically in the text by passus and line numbers. I have my colleagues Richard H. Godden and Michael Kuczynski to thank for drawing my attention to this episode's connection to scenes involving the tearing of petitions.

${ }^{59}$ It should be noted that "[asonder]" is one of several textual variations here ("atweyne" being the variant word). 
${ }^{60}$ See William Elford Rogers, Interpretation in "Piers Plowman" (Washington DC: Catholic Univ. Press of America, 2002), pp. 190-1; Anne Middleton, "Narration and the Invention of Experience: Episodic Form in Piers Plowman," in The Wisdom of Poetry: Essays in Early English Literature in Honor of Morton W. Bloomfield, ed. Larry D. Benson and Siegfried Wenzel (Kalamazoo: Western Michigan Univ. Press, 1982), pp. 91-122, 107-8; and Lawrence M. Clopper, "Songes of Rechelesnesse": Langland and the Franciscans (Ann Arbor: Univ. of Michigan Press, 1997), pp. 184-5.

${ }^{61}$ See Denise N. Baker, "From Plowing to Penitence: Piers Plowman and Fourteenth-Century Theology," Speculum 55, 4 (October 1980): 715-25; and Mary Carruthers, The Search for St. Truth: A Study of Meaning in "Piers Plowman" (Evanston IL: Northwestern Univ. Press, 1973), pp. 72-5.

${ }^{62}$ Chris McMahon describes "Hieronimo's rebellion ... as both an act of private revenge and a deed of civic responsibility" (Family and the State in Early Modern Revenge Drama: Economies of Vengeance [New York: Routledge, 2012], p. 66). Conversely, Andy Wood reads the consumption of sheep during Kett's Rebellion, the largest anti-enclosure rebellion of the sixteenth century, "as a collective act of revenge" (p. 165).

${ }^{63}$ Henry Knighton, Chronicon, ed. Joseph Rawson Lumby, The Chronicles and Memorials of Great Britain and Ireland during the Middle Ages 92, 3 (1895; rprt. London: Kraus, 1965), pp. 138-40, 139; qtd. in Ann W. Astell, "'Full of Enigmas': John Ball's Letters and Piers Plowman," in Political Allegory in Late Medieval England (Ithaca: Cornell Univ. Press, 1999), p. 57. See also Justice, Writing and Rebellion, pp. 102-39; and Richard Firth Green, “John Ball's Letters: Literary History and Historical Literature," in Chaucer's England: Literature in Historical Contexts, ed. Barbara A. Hanawalt (Minneapolis: Univ. of Minnesota Press, 1992), pp. 176-200. For a somewhat different assessment of the relation of the B-text to the Peasants' Revolt, see Hudson, "Piers Plowman and the Peasants' Revolt: A Problem Revisited," YLS 8 (1994): 85-106.

${ }^{64}$ See Justice, Writing and Rebellion, pp. 233-51, esp. 240-1; Ralph Hanna, "The 'Absent' Pardon-Tearing of Piers Plowman C," RESLJ 66, 275 (June 2015): 449-64; and Barr, "Major Episodes and Moments in Piers Plowman B," in The Cambridge Companion to "Piers Plowman," pp. 15-32, 24-5. See also Donaldson, Piers Plowman: The C-Text and Its Poet (New Haven: Yale Univ. Press, 1949), p. 108; Middleton, "The Idea of Public Poetry in the Reign of Richard II," Speculum 53, 1 (January 1978): 94-114, 98; and Kathryn Kerby-Fulton, "Langland and the Bibliographic Ego," in Written Work: Langland, Labor, and Authorship, ed. Justice and Kerby-Fulton (Philadelphia: Univ. of Pennsylvania Press, 1997), pp. 67-143.

${ }^{65}$ Much has been theorized about the authorship of the additions. For some recent appraisals, see Bruster, "Shakespearean Spellings and Handwriting in the Additional Passages Printed in the 1602 Spanish Tragedy," N\&Q 60, 3 (September 2013): 420-4; Arthur Freeman, "Thomas Hawkins, Richard Farmer, and the Authorship of The Spanish Tragedy," N\&Q 50, 2 (June 2003): 214-5; Rebekah Owens, "Thomas Hawkins's Attribution of the Authorship of The Spanish Tragedy," N\&Q 54, 1 (March 2007): 74-5; Emma Smith, "Author v. Character in Early Modern Dramatic Authorship: The Example of Thomas Kyd and The Spanish Tragedy," MRDE 11 (1999): 129-42; and Brian Vickers, "Identifying Shakespeare's Additions to The Spanish Tragedy (1602): A New(er) Approach," Shakespeare 8, 1 (April 2012): 13-43. 
${ }^{66}$ See, for example, Calvo and Tronch's note on this addition in Kyd, p. 245, note to III.xii.A. See also Kyd, The Spanish Tragedy, ed. Michael Neill (New York: Norton, 2014), p. xxxix.

${ }^{67}$ The pattern is not unlike Marcus's analysis of Quarto and folio versions of The Merry Wives of Windsor, The Taming of A/the Shrew, and Hamlet (pp. 68-176).

${ }^{68}$ I am thinking here of Coriolanus and a handful of other seventeenthcentury plays. Although I favor the argument that Nobody and Somebody was performed in the early 1590s, it may well turn out that the play was written in the early 1600s. Even so, its resonance with Knack suggests a certain nostalgia for the public theater of the early 1590s.

${ }^{69}$ There are many accounts of the acquisition of Blackfriars Theatre. Some useful starting points include Gurr, The Shakespeare Company, 1594-1643 (Cambridge: Cambridge Univ. Press, 2004), pp. 6-40; the essays collected in Inside Shakespeare: Essays on the Blackfriars Stage, ed. Paul Menzer (Selinsgrove PA: Susquehanna Univ. Press, 2006); and Moving Shakespeare Indoors: Performance and Repertoire in the Jacobean Playhouse, ed. Gurr and Karim-Cooper (Cambridge: Cambridge Univ. Press, 2014).

${ }^{70}$ See Gurr, The Shakespearean Stage, 1574-1642 (Cambridge: Cambridge Univ. Press, 2009), p. 104. On the Red Bull Theatre and its repertory, see Eva Griffith, A Jacobean Company and Its Playhouse: The Queen's Servants at the Red Bull Theatre (c. 1605-1619) (Cambridge: Cambridge Univ. Press, 2013).

${ }^{71}$ See Gurr, The Shakespeare Company, pp. 51-2, 218, 230, and 237. On the status of players, see Gurr, The Shakespearean Stage, pp. 100-12; and M. C. Bradbrook, The Rise of the Common Player: A Study of Actor and Society in Shakespeare's England (London: Chatto and Windus, 1962).

${ }^{72}$ Gurr, The Shakespeare Company, p. 51.

${ }^{73}$ John Marston, Jack Drum's Entertainment, ed. John S. Farmer, Tudor Facsimile Texts, facsimile of 1601 edn. ([Amersham UK]: Tudor Facsimile Texts, 1912), H3v.

${ }^{74}$ Richard Brome, The Antipodes: A Comedie (London: J. Okes for Francis Constable, 1640), D3v; EEBO STC (2d edn.) 3818. On the date for The Antipodes, see Matthew Steggle, Richard Brome: Place and Politics on the Caroline Stage (Manchester: Manchester Univ. Press, 2004), pp. 107-9.

${ }^{75}$ Marston, What You Will (London: G. Eld for Thomas Thorpe, 1607), A3r; EEBO STC (2d edn.) 17487. On the Children of Paul's, see Gurr, The Shakespearian Playing Companies (Oxford: Clarendon Press, 1996), pp. 337-46; and Reavley Gair, The Children of Paul's: The Story of a Theatre Company, 1553-1608 (Cambridge: Cambridge Univ. Press, 1982).

${ }^{76}$ Marston, What You Will, A3v.

${ }^{77}$ On sound, specifically music, in the indoor theaters, see Sarah Dustagheer, "Acoustic and Visual Practices Indoors," in Moving Shakespeare Indoors, pp. 137-51.

${ }^{78}$ Marston, What You Will, B3r. On lighting in the indoor theaters, see Martin White, "'When Torchlight Made an Artificial Noon': Light and Darkness in the Indoor Jacobean Theater," in Moving Shakespeare Indoors, pp. 115-36. ${ }^{79}$ Ibid. 